\title{
Expression patterns of mRNAs for methanotrophy and thiotrophy in symbionts of the hydrothermal vent mussel Bathymodiolus puteoserpentis
}

\author{
Annelie Wendeberg ${ }^{1,2,3}$, Frank U Zielinski ${ }^{1,3}$, Christian Borowski ${ }^{1}$ and Nicole Dubilier ${ }^{1}$ \\ ${ }^{1}$ Department of Molecular Ecology, Celsiusstr, Max Planck Institute for Marine Microbiology, Bremen, \\ Germany; ${ }^{2}$ Department of Geological and Planetary Sciences, California Institute of Technology, \\ Pasadena, CA, USA and ${ }^{3}$ Department of Environmental Microbiology, Helmholtz Centre for Environmental \\ Research-UFZ, Microbial Ecosystem Services Group, Leipzig, Germany
}

\begin{abstract}
The hydrothermal vent mussel Bathymodiolus puteoserpentis (Mytilidae) from the Mid-Atlantic Ridge hosts symbiotic sulfur- and methane-oxidizing bacteria in its gills. In this study, we investigated the activity and distribution of these two symbionts in juvenile mussels from the Logatchev hydrothermal vent field $\left(14^{4} 5^{\prime} \mathrm{N}\right.$ Mid-Atlantic Ridge). Expression patterns of two key genes for chemosynthesis were examined: pmoA (encoding subunit $A$ of the particulate methane monooxygenase) as an indicator for methanotrophy, and aprA (encoding the subunit $A$ of the dissimilatory adenosine-5'-phosphosulfate reductase) as an indicator for thiotrophy. Using simultaneous fluorescence in situ hybridization (FISH) of rRNA and mRNA we observed highest mRNA FISH signals toward the ciliated epithelium where seawater enters the gills. The levels of mRNA expression differed between individual specimens collected in a single grab from the same sampling site, whereas no obvious differences in symbiont abundance or distribution were observed. We propose that the symbionts respond to the steep temporal and spatial gradients in methane, reduced sulfur compounds and oxygen by modifying gene transcription, whereas changes in symbiont abundance and distribution take much longer than regulation of mRNA expression and may only occur in response to long-term changes in vent fluid geochemistry.
\end{abstract}

The ISME Journal (2012) 6, 104-112; doi:10.1038/ismej.2011.81; published online 7 July 2011

Subject Category: microbe-microbe and microbe-host interactions

Keywords: symbiosis; Bathymodiolus; mRNA FISH

\section{Introduction}

Bathymodiolin mussels (Bivalvia, Mytilidae) are found at hydrothermal vents and cold seeps around the world and harbor symbiotic bacteria in their gill tissues (DeChaine and Cavanaugh, 2006; Dubilier et al., 2008; Génio et al., 2008). Two types of symbiotic bacteria are common in bathymodiolin mussels, chemoautotrophic sulfur oxidizers or thiotrophs that use reduced sulfur compounds as electron donors and use $\mathrm{CO}_{2}$ as a carbon source, and methane oxidizers or methanotrophs that use methane both as an electron donor and as a source of carbon (DeChaine and Cavanaugh, 2006). Bathymodiolus puteoserpentis dominates the biological communities at two hydrothermal vents on the northern Mid-Atlantic Ridge, Snake Pit and

Correspondence: A Wendeberg, Department of Environmental Microbiology, Helmholtz Centre for Environmental ResearchUFZ, Microbial Ecosystem Services Group, Permoserstr 15, Leipzig 04318, Germany.

E-mail: annelie.pernthaler@ufz.de

Received 11 February 2011; revised 10 May 2011; accepted 17 May 2011; published online 7 July 2011
Logatchev (Maas et al., 1999; von Cosel et al., 1999; Gebruk et al., 2000). Comparative 16S rRNA sequence analysis of the symbionts in $B$. puteoserpentis revealed that these hosts live in a dual symbiosis with two gammaproteobacterial phylotypes related to the thiotrophic and methanotrophic symbionts of other bathymodiolin species (DeChaine and Cavanaugh, 2006; Duperron et al., 2006). Evidence for the use of methane as an energy source is based on ${ }^{14} \mathrm{CH}_{4}$ oxidation experiments, immunodetection of methanol dehydrogenase (a key enzyme in the methylotrophic oxidation of C1 substrates), hexulose-phosphate synthase assays (key enzyme of the ribulose monophosphate cycle of formaldehyde assimilation), amplification of genes coding for key enzymes in the oxidation of methane (methane monooxygenase (pmoA) and methanol dehydrogenyase (mxaF); Robinson et al., 1998; Pimenov et al., 2002) and $\delta^{13} \mathrm{C}$ data (Southward et al., 2001). In contrast, evidence for thiotrophy in $B$. puteoserpentis is inconclusive. Neither sulfide nor thiosulfate stimulated ${ }^{14} \mathrm{CO}_{2}$ fixation in the gill symbionts, and enzyme assays of the key enzyme for the assimilation of $\mathrm{CO}_{2}$ via the Calvin 
cycle (RubisCO—ribulose 1,5-bisphosphate carboxylase/oxygenase) were either negative or showed only low activities in two independent studies (Robinson et al., 1998; Pimenov et al., 2002). However, immunoblot analyses indicated the presence of RubisCO in $B$. puteoserpentis gill tissues (Robinson et al., 1998) suggesting that an autotrophic mode of nutrition is present beside methanotrophy.

One of the long-standing goals of environmental microbiology is to link the identity of individual organisms to their activity and biogeochemical impact. For identification, fluorescence in situ hybridization (FISH) with rRNA-targeted probes is routinely used (Amann and Fuchs, 2008). Analyzing the expression of functional genes that are diagnostic for a given metabolic pathway is an excellent tool for investigating the activity and physiology of an organism. In situ hybridization of mRNA sequences is a common technique for visualizing gene expression in eukaryotic cells and tissues, but has not been often used in studies on bacteria or archaea. Pernthaler and Amann (2004) developed a method for simultaneous FISH of rRNA and mRNA, using aerobic methane-oxidizing bacteria and a gene involved in methane oxidation ( $p m o A)$ as a model system.

In this study, our goal was to link the phylogenetic identity of the two symbionts in $B$. puteoserpentis with their metabolic ability to oxidize methane and reduced sulfur compounds using simultaneous FISH of rRNA and mRNA. To better understand how small-scale variability in environmental gradients affects symbiont abundance, distribution and activity within a single individual and between individuals, we analyzed eight $B$. puteoserpentis mussels collected from a single site with a net of $20 \mathrm{~cm}$ diameter at the Logatchev hydrothermal vent field (Gebruk et al., 2000; Petersen et al., 2009). At Logatchev, methane and sulfide are present at low millimolar concentrations in high-temperature fluids exiting black smokers (Douville et al., 2002; Schmidt et al., 2007) and at low micrometer concentrations in low-temperature diffuse fluids in the mussel beds (Schmidt et al., 2007; Perner et al., 2010). As a diagnostic marker for methanotrophy we used the $p m o A$ gene, which is commonly used to characterize aerobic methane-oxidizing bacteria (McDonald and Murrell, 1997; Jensen et al., 2000).
The pmoA gene codes for the subunit $\mathrm{A}$ of particulate methane monoxygenase and the enzyme catalyzes the oxidation of methane to methanol in all aerobic methanotrophs (Murrell et al., 2000). As a marker for thiotrophy we used the aprA gene, one of the key genes used to characterize chemoautotrophic sulfur-oxidizing bacteria (Blazejak et al., 2006; Meyer and Kuever, 2007). The aprA gene codes for the subunit A of the dissimilatory adenosine- $5^{\prime}$-phosphosulfate (APS) reductase (Hipp et al., 1997). In sulfur-oxidizing bacteria, APS reductase catalyzes the oxidation of sulfite and adenosine monophosphate to adenosine phosphosulfate (Sánchez et al., 2001).

\section{Materials and methods}

\section{Sample collection and preparation}

Using a net of $20 \mathrm{~cm}$ diameter, one single batch of mussels was collected from an overgrown sulfide structure by the ROV Quest (Marum, University of Bremen, Bremen, Germany) during the Hydromar I cruise (RV Meteor (M60/3), February 2004) at the Logatchev hydrothermal vent field on the MidAtlantic Ridge (IRINA II, $14^{\circ} 45.17^{\prime} \mathrm{N}, 44^{\circ} 58.75^{\prime} \mathrm{W}$ $( \pm 10 \mathrm{~m}), 3035 \mathrm{~m}$ depth). Upon recovery mussels were immediately transferred into chilled bottom seawater. Eight juvenile B. puteoserpentis (for size see Table 1) were picked from the mussel clump $14-16 \mathrm{~h}$ after sampling and fixed whole in $2 \%$ (weight/volume (w/v)) paraformaldehyde in $1 \times$ phosphate buffered saline (PBS, $\mathrm{pH}$ 7.6, $137 \mathrm{mM}$ $\mathrm{NaCl}, 2.7 \mathrm{mM} \mathrm{KCl}, 10 \mathrm{mM} \mathrm{Na}_{2} \mathrm{HPO}_{4}, 2 \mathrm{mM} \mathrm{KH} \mathrm{PO}_{4}$ ) for $\sim 10 \mathrm{~h}$ at $4{ }^{\circ} \mathrm{C}$. Specimens were washed three times in $1 \times$ PBS and placed into $50 \%(\mathrm{v} / \mathrm{v})$ ethanol in $1 \times$ PBS and stored for 8 weeks at $4{ }^{\circ} \mathrm{C}$. Specimens were then dehydrated in $70 \%(\mathrm{v} / \mathrm{v})$ ethanol and in $96 \%$ (v/v) ethanol for 1 day at $4{ }^{\circ} \mathrm{C}$, respectively, and stored in $96 \%(\mathrm{v} / \mathrm{v})$ ethanol at $-20^{\circ} \mathrm{C}$ for 1 week.

To permit observations of symbiont distribution and activity in $B$. puteoserpentis without altering the original positions of the mussel's organs (for example, gills, foot and visceral mass), the fixed mussels were embedded whole with their shells in wax and their shells dissolved subsequently through acid washing. The decalcification of embedded calcified tissue (for example, bones) with acids is a routine procedure in developmental biology for

Table 1 Summary of rRNA and mRNA FISH results and shell dimensions in juvenile Bathymodiolus puteoserpentis specimens

\begin{tabular}{|c|c|c|c|c|c|c|c|c|}
\hline Juvenile no. & 1 & 2 & 3 & 4 & 5 & 6 & 7 & 8 \\
\hline Shell length (mm) & 6.10 & 6.45 & 9.30 & 10.12 & 10.50 & 14.70 & 15.10 & 20.40 \\
\hline Shell width (mm) & 4.00 & 3.60 & 6.25 & 6.10 & 6.50 & 9.55 & 9.85 & 12.55 \\
\hline Symbionts in gills & Yes & Yes & Yes & Yes & Yes & Yes & Yes & Yes \\
\hline pmoA expression & ++ & ++ & + & + & - & ++ & ++ & + \\
\hline aprA expression & - & - & - & - & - & + & + & - \\
\hline
\end{tabular}

Abbreviation: FISH, fluorescence in situ hybridization.

$(++)$ strong mRNA FISH signal; (+) weak mRNA FISH signal; $(-)$ not detected. 
subsequent in situ hybridization of mRNAs (Shibata et al., 2000), and the soft tissues remain protected from the acid by the embedding medium. For embedding in Steedman's wax (Steedman, 1957), a small slit was cut into the ventral side of $B$. puteoserpentis shells, and the mussels were placed in $96 \%$ ethanol for $1 \mathrm{~h}$ at room temperature (RT), and in mixtures of 1 part wax and 2 parts ethanol, 1 part wax and 1 part ethanol, and 2 parts wax and 1 part ethanol, at $37^{\circ} \mathrm{C}$ for $1 \mathrm{~h}$ each. Mussels were placed in pure wax at $37^{\circ} \mathrm{C}$ for $1 \mathrm{~h}$ and left overnight in fresh wax at $37^{\circ} \mathrm{C}$, followed by another change of wax the next day. The wax was left to harden at RT for $3-4 \mathrm{~h}$ and then peeled off the mussel shells with a scalpel. The shells were rubbed clean with a tissue and placed into $2 \mathrm{M} \mathrm{HCl}$ for 30 60 min (depending on the size of the specimen) to remove the shell. The decalcified mussels were placed into a plastic mold filled with liquid wax and the block was left to harden at RT for $3-4 \mathrm{~h}$ or overnight. The blocks with the whole mussels were cut with a microtome into $10-\mu \mathrm{m}$-thick sequential frontal plane sections that were mounted on SuperfrostPlus slides (Menzel, Braunschweig, Germany). Sections were allowed to air dry over night and stored at $-20^{\circ} \mathrm{C}$.

Half of the block with juvenile 1 (Table 1) was lost during sectioning so that only a few sections were available for hybridizations of rRNA and mRNA, thus a full analysis of gene expression patterns or symbiont distribution over the whole gill as in all other seven specimens was not possible for this individual.

\section{FISH of rRNA}

Slides were placed in a glass tray and dewaxed in three successive baths of absolute ethanol for $5 \mathrm{~min}$ each. Sections were air dried and encircled with a rubber pen (Pap Pen, Kisker Biotechnology, Steinfurt, Germany). For rehydration, slides were placed in $70 \%$ ethanol for $5 \mathrm{~min}$. Hybridization with the general eubacterial probe (EUB338) and symbiont-specific probes targeting either the chemolithoautotrophic sulfur-oxidizing symbiont or the methane-oxidizing symbiont was carried out as described previously (Duperron et al., 2006).

\section{FISH of mRNA}

Details of amplification and sequencing of $p m o A$ and aprA genes, mRNA probe synthesis and controls for mRNA FISH are provided in the Supplementary material. Hybridization of mRNA was performed as described previously (Pernthaler and Amann, 2004) with some modifications in the permeabilization procedure. Sections were dewaxed and rehydrated as described above and carbethoxylated in freshly prepared $0.1 \%(\mathrm{v} / \mathrm{v})$ diethylpyrocarbonate in $1 \times \mathrm{PBS}$ for $12 \mathrm{~min}$ at RT. Slides were washed for $1 \mathrm{~min}$ each in $1 \times \mathrm{PBS}$ and MilliQ water (Millipore, Eschborn, Germany). For cell permeabilization and unmasking of mRNA, slides were placed into a glass container filled with $200 \mathrm{ml}$ of $10 \mathrm{mM}$ Na-citrate, $\mathrm{pH}$ 6.0. This container was placed into another glass container, filled with $350 \mathrm{ml}$ of tap water and heated in a microwave oven $(800 \mathrm{~W})$ on a rotating platform for $4 \mathrm{~min}$. The hot tap water was replaced by fresh tap water before microwaving for another $4 \mathrm{~min}$, during which the Na-citrate was allowed to boil for the last minute. After microwaving, the slides were kept in the hot buffer for $10 \mathrm{~min}$ and then placed into MilliQ water. Excess liquid was removed, and hybridization buffer pipetted onto the wet sections. The hybridization buffer consisted of $50 \%(\mathrm{v} / \mathrm{v})$ formamide, $2 \times$ saline sodium citrate buffer (SSC, $30 \mathrm{mM}$ sodium citrate, $0.3 \mathrm{M}$ sodium chloride), $10 \%$ (w/v) dextran sulfate, $1 \%(\mathrm{w} / \mathrm{v})$ blocking reagent (Boehringer, Mannheim, Germany), $1 \times$ Denhard's solution (Sigma, Taufkirchen, Germany), $0.2 \mathrm{mg} \mathrm{ml}^{-1}$ yeast RNA (Ambion, Huntington, UK), $0.2 \mathrm{mg} \mathrm{ml}^{-1}$ sheared salmon sperm DNA (Ambion) containing anti-sense probes for aprA, pmoA mRNA or the respective control probes (final concentration $0.25 \mathrm{ng}^{-1} \mathrm{l}^{-1}$ ). No prehybridization was performed. Hybridizations were carried out at $58^{\circ} \mathrm{C}$ for $12-18 \mathrm{~h}$. For stringent washing, slides were placed into $50 \%$ (v/v) formamide, $1 \times \mathrm{SSC}$ for $1 \mathrm{~h}$ at $58{ }^{\circ} \mathrm{C}$, followed by a $30 \mathrm{~min}$ wash in $0.2 \times$ SSC, $0.01 \%(\mathrm{w} / \mathrm{v})$ sodium dodecyl sulfate at $58{ }^{\circ} \mathrm{C}$. Slides were blocked in $1 \times$ PBS, $0.5 \%$ blocking reagent for $30 \mathrm{~min}$ at RT and incubated with an anti-fluorescein-horseradish peroxidase antibody (anti-FLUOS-HRP, Fab fragments, Roche Diagnostics, Mannheim, Germany $\left(0.75 \mathrm{U} \mathrm{ml}^{-1}\right)$ ), in $1 \times \mathrm{PBS}, 1 \%(\mathrm{w} / \mathrm{v})$ blocking reagent for $1.5-2 \mathrm{~h}$ at RT. Unbound antibody was removed by three washes in $1 \times$ PBS for $10 \mathrm{~min}$ each. The antibody was detected by incubation in Alexa ${ }_{488^{-}}$ labeled tyramide $\left(0.125 \mu \mathrm{g} \mathrm{ml}^{-1}\right)$ in amplification buffer $(1 \times \mathrm{PBS}, \mathrm{pH} 7.6,0.1 \%(\mathrm{w} / \mathrm{v})$ blocking reagent, $10 \%(\mathrm{w} / \mathrm{v})$ dextran sulfate, $2 \mathrm{M} \mathrm{NaCl}$, and freshly added $\left.0.0015 \%(\mathrm{v} / \mathrm{v}) \mathrm{H}_{2} \mathrm{O}_{2}\right)$ for $5 \mathrm{~min}$ at $37^{\circ} \mathrm{C}$. Piodophenylboronic acid was added to the tyramide solution (20 mg P-iodophenylboronic acid per $1 \mathrm{mg}$ tyramide, in dimethylformamide) to further enhance catalyzed reporter deposition (Bobrow et al., 2002). The tyramide was custom labeled as described previously (Pernthaler and Amann, 2004). Slides were washed in PBS for $3 \mathrm{~min}$, and three times with MilliQ water for 1 min each, dehydrated with $50 \%$ ethanol and absolute ethanol, respectively, and air dried. For subsequent rRNA FISH, probes targeting either the sulfur-oxidizing symbiont or the methaneoxidizing symbiont, were used as described previously (Duperron et al., 2006).

\section{Microscopic evaluation}

Tissue sections were covered in $4^{\prime}$-6-diamidino-2phenylindole -amended mountant (nine parts Citifluor (Leicester, UK), one part $1 \times \mathrm{PBS}, 1 \mu \mathrm{g} / \mathrm{ml}$ 4'-6-diamidino-2-phenylindole) and evaluated on a 
Axioskop II microscope (Zeiss, Jena, Germany) equipped with a HBO $100 \mathrm{~W}$ Hg vapor lamp, appropiate filter sets for Cy3/Alexa ${ }_{546}$, fluorescein/ Alexa $_{488}$, Cy5 and 4'-6-diamidino-2-phenylindole fluorescence, and $\times 10, \times 40$ and $\times 100$ Plan Apochromat objectives, and a Axiocam black-andwhite camera. The density of symbionts as well as the intensity of $p m o A$ and aprA mRNA FISH signals was determined by eye. Eight individuals were examined and, with the exception of juvenile 1 (see above), 10-20 slides per specimen were evaluated for symbiont distribution and 5-10 slides per specimen for mRNA FISH with three sections per slide for the two smallest specimens and up to six sections for bigger specimens. Images of mRNA and rRNA triple hybridizations were taken with a confocal laser scanning microscope (LSM510, Zeiss, Göttingen, Germany) equipped with helium-neon lasers (633 nm, $543 \mathrm{~nm}$ ) and an Argon laser (488 nm).

\section{Results and discussion}

Distribution of symbionts within the host

All investigated specimens harbored both symbionts in their gill bacteriocytes, the symbiont bearing host cells (Table 1). No obvious variations in the relative abundance of the two symbionts (as determined by eye) were observed between individuals (Supplementary Figure S1). Bacteriocytes adjacent to the ciliated epithelium were often more densely packed with symbionts than bacteriocytes elsewhere in the gill (Figures 1a-e, Supplementary Figures S1 and S2).

\section{Expression of pmoA and aprA in gill tissues}

The expression of $p m o A$ and $a p r A$ was investigated in the gill tissues of eight juvenile $B$. puteoserpentis specimens using simultaneous 16S rRNA and mRNA FISH. The $p m o A$ mRNA was only detected in the methanotrophic symbionts, indicating at the level of single-cell gene expression that these symbionts were actively oxidizing methane. This extends earlier studies (Pimenov et al., 2002) in which the $p m o A$ gene was amplified from the total DNA extract of $B$. puteoserpentis, and is consistent with evidence for methanotrophy using pmoA mRNA FISH in the closely related symbiont of Bathymodiolus azoricus mussels from the Rainbow hydrothermal vent field (Pernthaler and Amann, 2004).

The aprA mRNA was only detected in the chemoautotrophic symbionts (Figures 1c and d, Supplementary Figure S3) indicating that reduced sulfur compounds are utilized by the chemoautotrophic symbionts of $B$. puteoserpentis. This is the first direct evidence for thiotrophy in $B$. puteoserpentis symbionts as previous studies were not able to detect the thiotrophic activity in this host species (Robinson et al., 1998; Pimenov et al., 2002). Our results are consistent with evidence for thiotrophy in the closely related symbiont of $B$. azoricus mussels from more northern hydrothermal vents on the Mid-Altantic Ridge (Fiala-Medioni et al., 2002).

We detected pmoA mRNA in the gills of seven out of eight specimens (Table 1). Signal intensities of mRNA FISH (as determined by eye) were similar in both gills of each individual and weakened from posterior to anterior (Figure 1e). Strong pmoA mRNA FISH signals were detected in four mussels (juveniles 1, 2, 6 and 7) whereas the signals in three other individuals were comparatively weaker (juveniles 3, 4 and 8), and lacking altogether in one individual (juvenile 5). Juveniles 6 and 7 with strong pmoA mRNA FISH signals also showed aprA mRNA
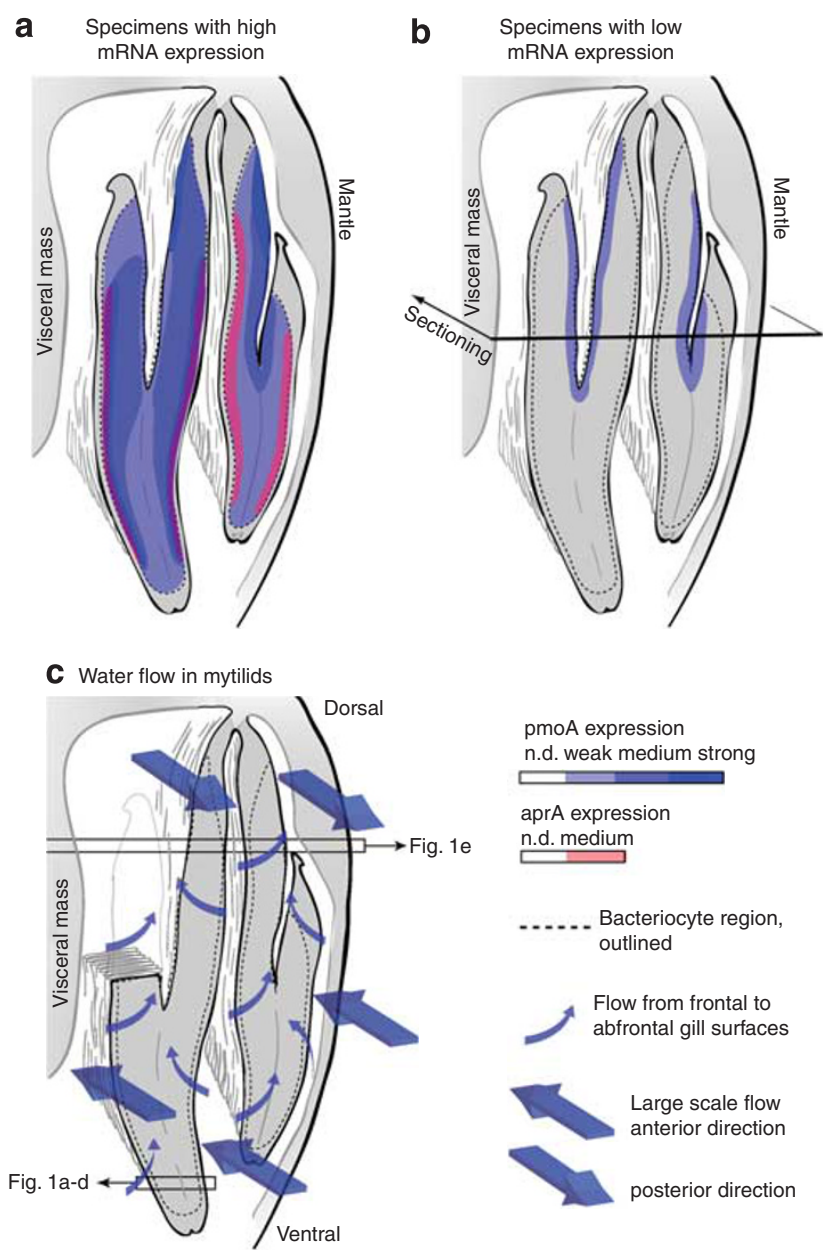

Figure 1 Schematic overview of the observed mRNA expression levels and proposed water flow in B. puteoserpentis gills. The drawings show a vertical cross-section of one gill through the dorsal-ventral axis. The view is from the posterior toward the anterior end of the gill. (a, b) Expression patterns of pmo $A$ and aprA, based on a projection of sequential plane sections. Expression of $p m o A$ was detected in all specimens except juvenile 5, whereas aprA mRNA was only detected in juveniles 6 and 7. (c) Proposed (simplified) water flow through the gills B. puteoserpentis based on current flow in Mytilus edulis (Ward et al., 1998). Boxes with arrows indicate approximate position of sections shown in Figure 1. n.d., not detected. 
FISH signals (Figures 1a-e, 2a; Supplementary Figure S1, Table 1). In individuals that showed strong aprA or pmoA expression, the signals for both genes were strongest close to the ciliated gill epithelia at the frontal (outer) edges of the infrabranchial chamber (the body cavity ventral to the gills; Figure 2a). In contrast, in juveniles 3, 4 and 8 with relatively weaker $p m o A$ expression levels these
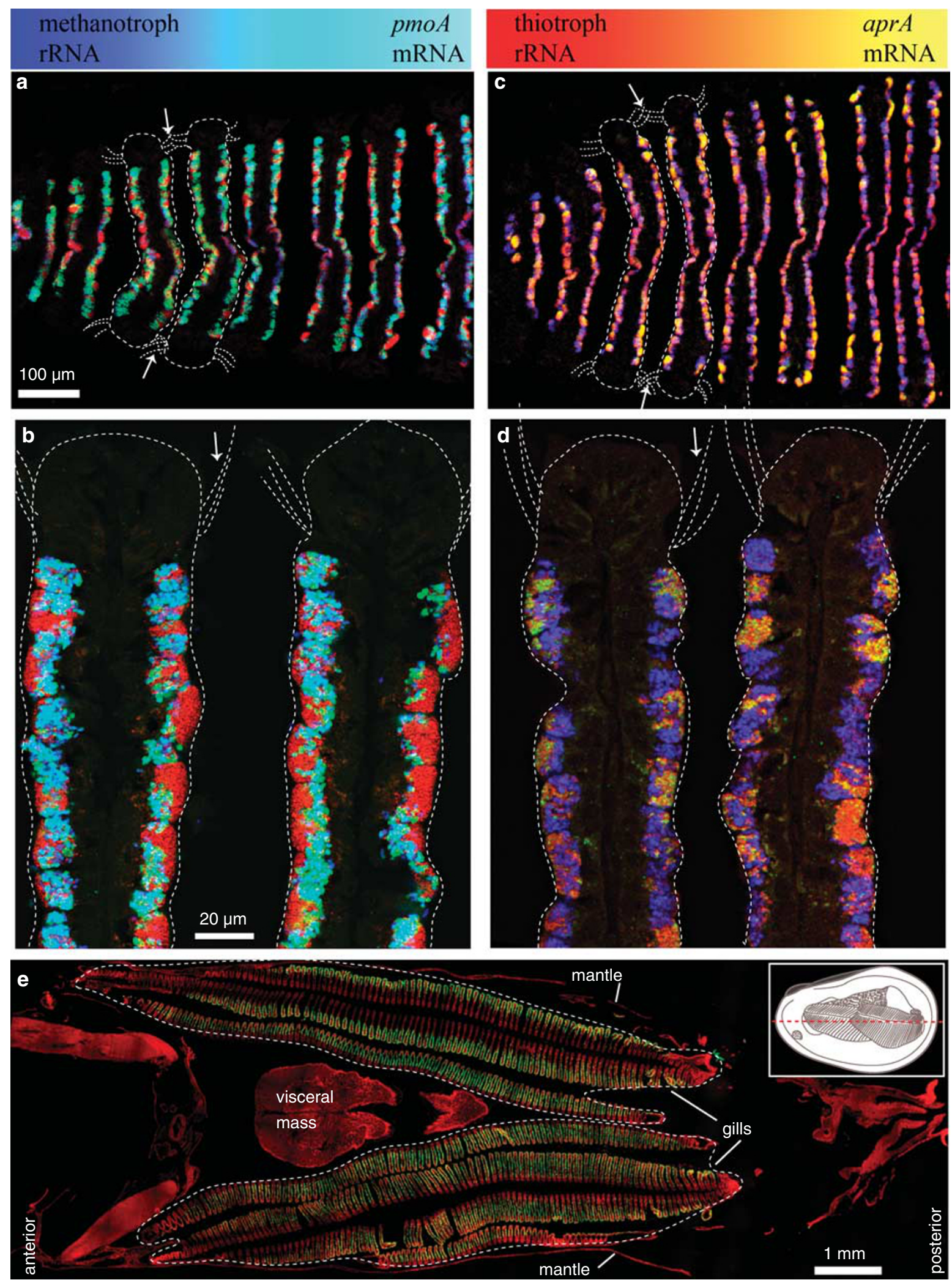
were only found in methanotrophs close to the suprabranchial chamber (the body cavity dorsal to the gills; Figure 2b, Table 1).

\section{High stability of pmoA mRNA}

Analyses of mRNA expression in deep-sea organisms are hampered by the fact that specimens are taken from their environment hours before they can be fixed on board, whereas the half-life of mRNAs can be as short as a fraction of a minute (Deana and Belasco, 2005). However, not all mRNAs are highly instable. Many have a half-life of several hours, for example, amoA mRNA, coding for ammonia monooxygenase; (Sayavedra-Soto et al., 1996). In general, bacterial mRNAs that are actively translated are very stable in comparison with their non-translated counterparts (Deana and Belasco, 2005). PmoA mRNA can be readily isolated from soil (Chen et al., 2008), even after storage at $4{ }^{\circ} \mathrm{C}$ for several days (JC Murrell, personal communication), indicating a high stability of $p m o A$ transcripts. In our study, despite the delay of 14-16 h between sampling of $B$. puteoserpentis mussels at $3000 \mathrm{~m}$ water depth and their fixation on board, we were able to detect strong pmoA mRNA FISH signals, suggesting that the half life of this mRNA is in the range of hours to possibly days.

\section{Low aprA expression levels}

The lack of detectable aprA expression in the majority of the sampled mussels is surprising, if one assumes that the high density and strong rRNA FISH signals of the thiotrophic symbionts observed in all B. puteoserpentis individuals reflects a sufficient supply with reduced sulfur compounds, at least over longer time periods. However, shortterm differences in the delivery of reduced sulfur compounds could be one explanation for the weak expression of aprA. Alternative explanations are that (1) aprA mRNA is degraded faster than pmoA mRNA, (2) the sensitivity of the aprA probe was lower than that of the pmoA probe, or (3) the turnover rates of APS reductase are low, causing low levels of mRNA. Furthermore, it is possible that APS reductase is not the main enzyme used by the thiotrophic symbionts for oxidizing sulfite, but that alternative pathways for dissimilatory sulfite oxida- tion are predominantly used (Sánchez et al., 2001; Scott et al., 2006; Kappler et al., 2008). For example, the genes of the sulfur oxidation system could be used alternatively. Sulfur oxidation system genes (as well as aprA genes) have been found in the genomes of gammaproteobacterial thiotrophic symbionts from other hosts such as gutless oligochaetes, vesicomyid clams and hydrothermal vent tubeworms (Woyke et al., 2006; Kuwahara et al., 2007; Meyer and Kuever, 2007; Newton et al., 2007; Robidart et al., 2008). Finally, reduced sulfur compounds may not be the only energy source for the thiotrophic symbionts. Free-living sulfur-oxidizing bacteria can also use other energy sources beside reduced sulfur compounds, such as hydrogen (Drobner et al., 1990; Ohmura et al., 2002; Beller et al., 2006; Scott et al., 2006), which is present at high concentrations in the vent fluids at Logatchev (Schmidt et al., 2007). There is no published data on the genomes of bathymodiolin symbionts, but sequencing of the genomes of Bathymodiolus sp symbionts from the southern Mid-Atlantic Ridge is now in progress. Preliminary analyses show that the genes for both pathways of dissimilatory sulfite oxidation ( $a p r A B C$ and sulfur oxidation system genes) as well as the genes for hydrogen oxidation (hupSL) are present in the thiotrophic symbionts of these vent mussels (Dubilier et al., unpublished data).

\section{Expression patterns and delivery of oxygen, methane} and sulfide

Bathymodiolin mussels do not contain binding proteins to deliver methane, sulfide and oxygen dissolved in the diffuse vent fluids and surrounding seawater to their symbionts (Childress and Fisher, 1992). Therefore, the flow of water along the mussel gills, as well as advection and diffusion are critical for the transport of reductants and oxidants to their symbionts. Nothing is currently known about the water flow along the gills of deep-water bivalves. In shallow-water mussels, seawater is pumped through the inhalent siphon along the ventral parts of the gill from posterior to anterior, and then returns from anterior to posterior along the dorsal part of the gill and exits through the exhalent siphon (Figure 2c). In more detail, when the water first enters through the inhalent siphon, it flows

Figure 2 Simultaneous FISH of rRNA and mRNA on cross-sections of juvenile $B$. puteoserpentis. Color panels at the top of the figure show the level of mRNA expression (colors on the left of the two panels indicate no mRNA expression and colors on the right show high expression levels). See Figure 2c for diagram showing where in the gills sections were taken. (a-d) Juvenile 6 with simultaneous FISH of mRNA (green) and rRNA of thiotrophic (red) and methanotrophic (blue) symbionts. Two gill filaments and the cilia at their frontal edges are outlined in each image (white dotted lines, arrows show the direction in which seawater and vent fluids enter the gills). (a) m/rRNA of methanotrophic symbionts. Methanotrophs with high pmoA expression levels appear turquoise, close to the ciliated epithelium (arrows), methanotrophs with low pmoA expression levels appear blue (center). (b) Detail of (a), a few thiotrophs in the immediate vicinity of methanotrophs appear yellow, caused by a strong pmoA mRNA FISH signal of the methanotrophic neighbor. (c) m/rRNA FISH of thiotrophic symbionts. Thiotrophs with aprA expression appear yellow close to the ciliated epithelium (arrows), thiotrophs without aprA expression appear red (center). (d) Detail of (c). (e) Horizontal cross-section through a whole mussel in the posterior-anterior axis (juvenile 7). DAPI (red) and pmoA mRNA FISH (green), with gills outlined (white dotted line). The inset in (e) shows a schematic drawing of a juvenile mussel with one shell removed; the red dotted line indicates the sectioning plane of the cross-section shown in (e). 
along the ventral edge of the gill from posterior to anterior with part of the water flowing from dorsal to ventral along the ciliated frontal surfaces of the infrabranchial chamber and part of the water flowing laterally through the gills from the frontal to the abfrontal regions (Figure 2c). The seawater leaves the mussels through the dorsal suprabranchial chamber in anterior-posterior direction, and is pumped out through the exhalent siphon (Beninger et al., 1997).

In deep-sea bathymodiolin mussels, the symbiontcontaining gills are enlarged and take up more space in the mantle cavity (the chamber between the shell and the soft-tissue parts of the mussel) than the gills of shallow water mytilids. It is likely, however, given the general conformity of gill and siphon morphology in all mytilids that the water flow patterns in $B$. puteoserpentis are similar to those of shallow-water mussels. We therefore assume that the incoming water, which is enriched in reductants and oxidants, first flows in the infrabranchial chamber along the frontal edges of the ventral gill surfaces from posterior to anterior. This corresponds well with our observations of mRNA expression patterns in individuals with high levels of $p m o A$ and aprA expression: These were highest for both genes in symbionts close to the ciliated frontal surfaces at the posterior ends of the infrabranchial chamber with a clear decrease in signal intensities toward the anterior gill ends (Figures 1e and 2a). In symbionts more distant from the frontal surface, mRNA expression levels were lower, indicating that these receive less methane, sulfide and oxygen because of their consumption by the symbionts in the frontal regions of the gill (Figures 1a,b, 2a and Supplementary Figure S3). FISH mRNA signals were also strong in the suprabranchial chamber of individuals with overall high mRNA expression levels (Figure 2a). Residual components of the posterior-anterior and the ventral-dorsal flows most probably merge and exit with the exhalent flow in the suprabranchial chamber. As these reversal flow components do not pass through the symbiontcontaining gill filaments, they may still contain considerable concentrations of reductants and oxidants.

In individuals with overall low mRNA expression levels it is not clear why pmoA FISH signals were only found in symbionts close to the suprabranchial chamber (Figure 2b). It is possible that differences in mRNA degradation rates in response to individual stress levels in specimens before their fixation influenced the levels of residual mRNA.

\section{Conclusions}

The abundance and distribution of both the sulfur- and methane-oxidizing symbionts was not noticeably different in all eight mussel individuals.
In contrast, mRNA expresssion levels varied markedly despite the collection of all eight mussels in one grab from a single sampling site. These large differences in transcriptional activity may reflect the conditions under which mussels live at hydrothermal vents. Gradients in vent fluids can be very steep and change rapidly (Fisher et al., 1987, 2007; Johnson et al., 1988a, b; Le Bris et al., 2006). It would therefore be energetically favorable for the symbionts to respond to these short-term variations in substrate availability with changes in transcriptional activity that can provide adaptations within a short time. In contrast, changes in symbiont abundance involve interactions between the symbiont and the host that can take days to weeks (Kadar et al., 2005; Riou et al., 2008), and would therefore only be energetically favorable after longterm changes in vent geochemistry. For future studies, we are developing in situ instruments that will allow the fixation of mussels in the deep-sea and provide a more detailed understanding of how symbiont abundance, distribution and activity are influenced by spatial and temporal gradients in vent geochemistry.

\section{Acknowledgements}

We are grateful to Silke Wetzel for excellent technical assistance, and Rudi Amann and Shana Goffredi for critical reading of the manuscript and valuable discussions. We thank the chief scientist Thomas Kuhn and the captain of the Hydromar I cruise as well as the crews of the RV Meteor and the ROV Quest (MARUM, University of Bremen, Germany). This work was supported by the Priority Program 1144 'From Mantle to Ocean: Energy-, Material- and Life-cycles at Spreading Axes' (Contribution number 58) of the German Science Foundation (DFG), the DFG-Research Center/Excellence Cluster 'The Ocean in the Earth System' at MARUM, and the Max Planck Society.

\section{References}

Amann RI, Fuchs BM. (2008). Single-cell identification in microbial communities by improved fluorescence in situ hybridization techniques. Nature Rev Microbiol 6: 339-348.

Beller HR, Chain PS, Letain TE, Chakicherla A, Larimer FW, Richardson PM et al. (2006). The genome sequence of the obligately chemolithoautotrophic, facultatively anaerobic bacterium Thiobacillus denitrificans. J Bacteriol 188: 1473-14488.

Beninger PG, Lynn JW, Dietz TH, Silverman H. (1997). Mucociliary transport in living tissue: the two-layer model confirmed in the mussel Mytilus edulis L. Bio Bull 193: 4-7.

Blazejak A, Küver J, Erséus C, Amann R, Dubilier N. (2006). Phylogeny of $16 \mathrm{~S}$ rRNA, RubisCO, and APS reductase genes from gamma- and alphaproteobacterial symbionts in gutless marine worms (Oligochaeta) 
from Bermuda and Bahamas. Appl Environ Microbiol 71: 1553-1561.

Bobrow MN, Adler KE, Roth A. (2002). Enhanced Catalyzed Reporter Deposition. Bobrow: MN, USA.

Chen Y, Dumont MG, McNamara NP, Chamberlain PM, Bodrossy L, Stralis-Pavese N et al. (2008). Diversity of the active methanotrophic community in acidic peatland as assessed by mRNA and SIP-PLFA analyses. Environ Microbiol 10: 446-459.

Childress JJ, Fisher CR. (1992). The biology of hydrothermal vent animals: physiology, biochemistry, and autotrophic symbioses. Oceano Mar Biol Ann Rev 30: 337-441.

Deana A, Belasco JG. (2005). Lost in translation: the influence of ribosomes on bacterial mRNA decay. Genes Dev 19: 2526-2533.

DeChaine EG, Cavanaugh CM. (2006). Symbioses of methanotrops and deep-sea mussels (Mytilidae: Bathymodiolinae). In: Overmann J (ed.). Molecular Basis of Symbiosis. Springer Verlag: Berlin.

Douville E, Charlou JL, Oelkers EH, Bienvenu P, Jove Colon CF, Donval JP et al. (2002). The rainbow vent fluids $\left(36^{\circ} 14^{\prime} \mathrm{N}, \mathrm{MAR}\right)$ : the influence of ultramafic rocks and phase separation on trace metal content in Mid-Atlantic Ridge hydrothermal fluids. Chem Geol 184: $37-48$.

Drobner E, Huber H, Stetter KO. (1990). Thiobacillus ferrooxidans, a facultative hydrogen oxidizer. Appl Environ Microbiol 56: 2922-2923.

Dubilier N, Bergin C, Lott C. (2008). Symbiotic diversity in marine animals: the art of harnessing chemosynthesis. Nat Rev Microbiol 6: 725-740.

Duperron S, Bergin C, Zielinski F, Blazejak A, Pernthaler A, McKinnes ZP et al. (2006). A dual symbiosis shared by two mussel species, Bathymodiolus azoricus and $B$. puteoserpentis (Bivalvia: Mytilidae) from hydrothermal vents along the Mid-Atlantic Ridge. Environ Microbiol 8: 1441-1447.

Fiala-Medioni A, McKiness ZP, Dando P, Boulegue J, Mariotti A, Alayse-Danet AM et al. (2002). Ultrastructural, biochemical, and immunological characterization of two populations of the mytilid mussel Bathymodiolus azoricus from the Mid-Atlantic Ridge: evidence for a dual symbiosis. Mar Biol 141: 1035-1043.

Fisher CR, Childress JJ, Oremland RS, Bidigare RR. (1987). The importance of methane and thiosulfate in the metabolism of the bacterial symbionts of two deep-sea mussels. Mar Biol 96: 59-71.

Fisher CR, Takai K, Le Bris N. (2007). Hydrothermal vent ecosystems. Oceanography 20: 14-23.

Gebruk AV, Chevaldonne P, Shank T, Lutz RA, Vrijenhoek RC. (2000). Deep-sea hydrothermal vent communities of the Logatchev area (14 degrees $45^{\prime} \mathrm{N}$, Mid-Atlantic Ridge): diverse biotopes and high biomass. J Mar Biol AsSOC UK 80: 383-393.

Génio L, Johnson SB, Vrijenhoek RC, Cunha MR, Tyler PA, Kiel S et al. (2008). New record of 'Bathymodiolus' mauritanicus Cosel 2002 from the Gulf of Cadiz (NE Atlantic) mud molcanoes. J Shellf Res 27: 53-61.

Hipp WM, Pott AS, Thum-Schmitz N, Faath I, Dahl C, Trüper HG. (1997). Towards the phylogeny of APS reductases and sirohaem sulfite reductases in sulfatereducing ans sulfur-oxidizing prokaryotes. Microbiol 143: 2891-2902.
Jensen S, Holmes AJ, Olsen AR, Murrell CJ. (2000). Detection of methane oxidizing bacteria in forest soil by monooxygenase PCR amplification. Microb Ecol 39: 282-289.

Johnson KS, Childress JJ, Beehler CL. (1988a). Short-term temperature variability in the Rose Garden hydrothermal vent field: an unstable deep-sea environment. Deep-Sea Res A Oceanogr Res Pap 35: 1711-1721.

Johnson KS, Childress JJ, Hessler RR, Sakamoto-Arnold CM, Beehler CL. (1988b). Chemical and biological interactions in the Rose Garden hydrothermal vent field, Galapagos spreading center. Deep-Sea Res A Oceanogr Res Pap 35: 1723-1744.

Kadar E, Bettencourt R, Costa V, Santos RS, Lobo-daCunha A, Dando PR. (2005). Experimentally induced endosymbiont loss and re-acquirement in the hydrothermal vent bivalve Bathymodiolus azoricus. J Exp Mar Biol Ecol 318: 99-110.

Kappler U, Bernhardt PV, Kilmartin J, Riley MJ, Teschner J, McKenzie KJ et al. (2008). SoxAX cytochromes, a new type of heme copper protein involved in bacterial energy generation from sulfur compounds. J Biol Chem 283: 22206-22214.

Kuwahara H, Yoshida T, Takaki Y, Shimamura S, Nishi S, Harada $\mathrm{M}$ et al. (2007). Reduced genome of the thioautotrophic intracellular symbiont in a deep-sea clam, Calyptogena okutanii. Curr Biol 17: 881-886.

Le Bris N, Govenar B, Le Gall C, Fisher CR. (2006). Variability of physico-chemical conditions in $9^{\circ} 50^{\prime} \mathrm{N}$ EPR diffuse flow vent habitats. Mar Chem 98: 167-182.

Maas PAY, O’Mullan GD, Lutz RA, Vrijenhoek RC. (1999). Genetic and morphometric characterization of mussels (Bivalvia: Mytilidae) from Mid-Atlantic hydrothermal vents. Bio Bull 196: 265-272.

McDonald IR, Murrell CJ. (1997). The particulate methane monooxygenase gene pmoA and its use as a functional gene probe for methanotrophs. FEMS Microbiol Lett 156: 205-210.

Meyer B, Kuever J. (2007). Molecular analysis of the diversity of sulfate-reducing and sulfur-oxidizing prokaryotes in the environment, using aprA as a functional marker gene. Appl Environ Microbiol 73: 7664-7679.

Murrell CJ, Gilbert B, McDonald IR. (2000). Molecular biology and regulation of methane monooxygenase. Arch Microbiol 173: 325-332.

Newton ILG, Woyke T, Auchtung TA, Dilly GF, Dutton RJ, Fisher MC et al. (2007). The Calyptogena magnifica chemoautotrophic symbiont genome. Science 315: 998-1000.

Ohmura N, Sasaki K, Matsumoto N, Saiki H. (2002). Anaerobic respiration using $\mathrm{Fe}^{3+}, \mathrm{S}^{0}$, and $\mathrm{H}_{2}$ in the chemolithoautotrophic bacterium Acidithiobacillus ferrooxidans. J Bacteriol 184: 2081-2087.

Perner M, Petersen JM, Zielinski F, Gennerich HH, Seifert R. (2010). Geochemical constraints on the diversity and activity of H2-oxidizing microorganisms in diffuse hydrothermal fluids from a basalt- and an ultramafic-hosted vent. FEMS Microbiol Ecol 74: $55-71$.

Pernthaler A, Amann R. (2004). Simultaneous fluorescence in situ hybridization of mRNA and rRNA in environmental bacteria. Appl Environ Microbiol 70: 5426-5433.

Petersen S, Kuhn K, Kuhn T, Augustin N, Hekinian R, Franz L et al. (2009). The geological setting of the 
ultramafic-hosted Logatchev hydrothermal field $\left(14^{\circ} 45^{\prime} \mathrm{N}\right.$, Mid-Atlantic Ridge) and its influence on massive sulfide formation. Lithos 112: 40-56.

Pimenov NV, Kalyuzhnaya MG, Khmelenina VN, Mityushina LL, Trotsenko YA. (2002). Utilization of methane and carbon dioxide by symbiotrophic bacteria in gills of Mytilidae (Bathymodiolus) from the Rainbow and Logatchev hydrothermal vent fields on the Mid-Atlantic Ridge. Microbiol 71: 587-594.

Riou V, Halary S, Duperron S, Bouillon S, Elskens M, Bettencourt $\mathrm{R}$ et al. (2008). Influence of $\mathrm{CH}_{4}$ and $\mathrm{H}_{2} \mathrm{~S}$ availability on symbiont distribution, carbon assimilation and transfer in the dual symbiotic vent mussel Bathymodiolus azoricus. Biogeosciences 5: 1681-1691.

Robidart JC, Bench SR, Feldman R, Podell S, Novoradovsky A, Gaasterland $\mathrm{T}$ et al. (2008). Metabolic versatility of the Riftia pachyptila endosymbiont revealed through metagenomics. Environ Microbiol 10: 727-737.

Robinson JJ, Polz MF, Fiala-Medioni A, Cavanaugh CM. (1998). Physiological and immunological evidence for two distinct $\mathrm{C}_{1}$-utilizing pathways in Bathymodiolus puteoserpentis (Bivalvia: Mytilidae), a dual endosymbiotic mussel from the Mid-Atlantic Ridge. Mar Biol 132: $625-633$

Sánchez O, Ferrera I, Dahl C, Mas J. (2001). In vivo role of adenosine- $5^{\prime}$-phosphosulfate reductase in the purple sulfur bacterium Allochromatium vinosum. Arch Microbiol 176: 301-305.

Sayavedra-Soto LA, Hommes NG, Russell SA, Arp DJ. (1996). Induction of ammonia monooxygenase and hydroxylamine oxidoreductase mRNAs by ammonium in Nitrosomonas europaea. Mol Microbiol 20: 541-548.
Schmidt K, Koschinsky A, Garbe-Schönberg D, de Carvalho LM, Seifert R. (2007). Geochemistry of hydrothermal vent fluids the ultramafic-hosted Logatchev hydrothermal field, $15^{\circ} \mathrm{N}$ on the MidAtlantic Ridge: temporal and spatial investigation. Chem Geol 242: 1-21.

Scott KM, Sievert SM, Abril FN, Ball LA, Barrett CJ, Blake RA et al. (2006). The genome of deep-sea vent chemolithoautotroph Thiomicrospira crunogena XCL-2. PLOS Biology 4: 2196-2212.

Shibata Y, Fujita S, Takahashi H, Yamaguchi A, Koji T. (2000). Assessment of decalcifying protocols for detection of specific RNA by non-radioactive in situ hybridization in calcified tissues. Histoch Cell Biol 113: 153-159.

Southward EC, Gebruk AV, Kennedy H, Southward AJ, Chevaldonne P. (2001). Different energy sources for three symbiont-dependent bivalve molluscs at the Logatchev hydrothermal site (Mid Atlantic Ridge). J Mar Biol Assoc UK 81: 656-661.

Steedman HF. (1957). Polyester wax. A new ribboning embedding medium for histology. Nature 4574: 1345.

von Cosel RT, Comtet T, Krylova E. (1999). Bathymodiolus (Bivalvia: Mytilidae) from hydrothermal vents on the Azores Triple Junction and the Logatchev Hydrothermal Field, Mid-Atlantic Ridge. Veliger 42: 218-248.

Ward JE, Sanford LP, Newell RIE, Thompson RJ, MacDonald BA. (1998). A new explanation of particle capture in suspension-feeding bivalve molluscs. Limnol Oceanogr 43: 741-752.

Woyke T, Teeling $\mathrm{H}$, Ivanova NN, Huntemann $\mathrm{M}$, Richter M, Glöckner FO et al. (2006). Symbiosis insights through metagenomic analysis of a microbial consortium. Nature 443: 950-955.

Supplementary Information accompanies the paper on The ISME Journal website (http://www.nature.com/ismej) 